\title{
CORRECTION
}

\section{Correction to: Antibiotic resistance and molecular characterization of poultry isolates of Salmonella by RAPD-PCR}

Youg Raj Thaker ${ }^{1} \cdot$ Bijender K. Bajaj ${ }^{2}$

Published online: 23 September 2019

(c) Springer Nature B.V. 2019

\section{Correction to: \\ World J Microbiol Biotechnol (2006) 22:1177-1183 \\ https://doi.org/10.1007/s11274-006-9159-8}

Unfortunately, The first author's name has been incorrectly published in the original publication of the article. The correct name of the author is "Youg Raj Thaker".
Publisher's Note Springer Nature remains neutral with regard to jurisdictional claims in published maps and institutional affiliations.

The original article can be found online at https://doi.org/10.1007/ s11274-006-9159-8.

Bijender K. Bajaj

bkbajaj1@ rediffmail.com

1 Department of Biotechnology, University of Jammu, Jammu 180 006, India

2 School of Biotechnology, Shri Mata Vaishno Devi University, Railway Head Complex, Jammu, Kakrial, Udhampur, J\&K 182121, India 